\title{
Which ideas should guide US Foreign Policy? Holding fundamentalist policy paradigms to account
}

\author{
Dr Matthew Johnson ${ }^{1}$ and Dr Russell Foster ${ }^{2}$
}

This is an Author's Original Manuscript (AOM) of an article published by Springer in International Politics, available online:

\begin{abstract}
In this article, we trace the failure of neoconservative and neoliberal thinkers to revise positions in light of changing US fortunes to highlight the need to evaluate paradigmatic contributions to US Foreign Policy. Drawing on the philosophy of science literature, we suggest that, in order for approaches to be taken seriously, their proponents ought to present means of their own falsification. We argue that the obstinacy of paradigms is not merely of academic importance, since such approaches may contribute to the very crises they claim to resolve. This should give policy makers reasons to reject them as fundamentalist.
\end{abstract}

Keywords: American empire; neoconservatism; neoliberalism; paradigms; Donald Trump

\section{Introduction}

The first months of President Trump's 'America First' policy (Ferguson 2017) led Presidential biographer Nigel Hamilton (2017) to lament the retreat from interventionism to isolationism as evidence of imminent, inevitable and irreversible decline of American Empire. In the face of internal political and social deterioration and cultural conflict (Bacevich 2017), climate change (Sullivan 2018) and the rise of rival powers, Hamilton (2017: 27) prophesies that 'the US may well revert to the Dust Bowl'. Such bleakness stands in stark contrast to narratives of American expansion and Empire at the beginning of the millennium. While some realists, such as Kenneth Pomeranz (2005) and CIA agent-turned-scholar Chalmers Johnson (2004), have long expressed caution about American Empire for fear that its decline would herald the decline of America itself, the late 1990s and early 2000s (although as this paper argues, elements of this still survive today) witnessed a range of paradigmatic approaches united in belief that American power was in the ascendancy (Hopkins 2018, Pomper 2005) and vital to global peace (Kaplan and Kristol, 2003). Spurred by the dissolution of the Soviet Union, the rapid expansion of global capitalism and the apparent geostrategic victories of the US campaigns in Afghanistan and then Iraq (Kaplan and Kristol 2003), neoconservative and neoliberal thinkers achieved relative consensus that the US was a force with the means (Parker 2010) and motive (Pomeranz 2005) to expand further. While they disagreed about the nature and viability of empire, elements of these domestic US narratives merged and intermeshed in ways that they had not previously.

However, seismic events in recent years, from the failings of the Global War on Terror, the Financial Crisis, Great Recession and onset of austerity, and, now, President Trump's inconsistent isolationism, provide ample prima facie reason for narrative and policy revision. The resistance of these two paradigms to revision would, of course, be strictly 'academic' were political actors not informed seriously by the work of scholars and their claims of 'scientific'

\footnotetext{
${ }^{1}$ Senior Lecturer in Politics, Department of Politics, Philosophy and Religion, Lancaster University

${ }^{2}$ Lecturer in British and European Politics (AEP) in the Department of European and International Studies, King's College London
} 
legitimacy. Indeed, the impact of that scholarly work may be seen in those crises that have defined the past decade.

In this article, we seek to make the case for 'scientific' examination of neoconservatism and neoliberalism in order to establish their value to policy makers. First, we make a renewed case for concern for 'falsifiability', arguing that the lack of criteria by which to refute the approaches leads to post-act rationalization that serves to separate narrative from events through externalization of responsibility for crises. We trace examples of the approaches' narratives as individuals grapple with shifting 'facts on the ground'. We show that, in both paradigms, the seismic events of the twenty-first century have been insufficient, radically, to alter analyses qualitatively. This, we argue, is the consequence of neoconservatism's and neoliberalism's fetishization of related features of American society developed during US imperial expansion. Ultimately, we suggest that the fundamentalism of these commitments should disqualify them from informing policy, since the consequences of their proponents' being wrong are so grave. We begin by emphasizing the importance of ideas and outlining the case for falsifiability by drawing on the canon of philosophy of science literature, before introducing the American Empire discourse that contributed to the present condition.

\section{The importance of ideas}

There is, of course, substantive debate about the extent to which ideas matter. Materialists and idealists have, for centuries, disagreed about the determinacy of ideas. However, there is evidence, not least the differences in foreign policy pursued by the Bush, Obama and Trump Presidencies, that paradigmatic approaches have the capacity to inform key actors within the state, even if other elements of the state retain contrary positions. The way in which neoliberal ideas emerged in the 1970s as a heterodox cluster of radical analytical and normative tenets espoused by fringe economists to shape policy, first, among the leaders of the US, UK and other states and then, gradually, international organizations in general, is demonstrative of the capacity of activist intellectuals to achieve influence, apparently against the odds. An ontology of the state and a theory of the mechanism of influence are beyond the scope of this article, precisely because political institutions and forms of influence are necessarily particular. Here, we wish merely to emphasize that the pathway to influence is complex and necessarily shaped by specific political, economic and social circumstances. Those circumstances limit the range of ideas capable of achieving influence insofar as there must be some elective affinity of ideas within a society and within the state, such that ideas make sense to those exercising power and, within democratic societies, portions of the electorate that grant authority to those actors. That is to say, while not all ideas are capable of achieving influence by virtue of their lack of affinity with other elements in a society, the outcomes of the 2016 UK Referendum on Membership of the European Union and the 2017 US Presidential Election demonstrate that a wider range of ideas have the capacity to inform policy than might previously have been thought. While those two events have shaken faith in 'experts' and 'expertise', and while the embeddedness of ideas in institutions necessarily restricts agency (see Cahill 2017), there remains good reason to hold proponents of positions on foreign policy to account according to the extent to which paradigms reflect accurately the unfolding events of human affairs and support approaches that advance the interests of human beings. This can only be achieved by demanding that paradigms present means of their own refutation as they seek influence in policy circles.

\section{The importance of falsifiability}

There has been, of course, a long-running debate about the means of defining science philosophically. Perhaps the core tenet of Western philosophy from Plato and Aristotle, through Aquinas and Kant, to the 20th century, was that there exists an objective reality independent of fallible human perception, knowledge or language. As part of this tradition, 
science has been seen to rest upon, what Rorty (1980) terms, a 'Platonic/Aristotelian dualist' foundation. For empiricists, the telos of science is 'realist': to represent, reflect, and explain in human terms, reality. Of particular importance is the positivist belief that explanation entails the identification of universal laws by which existence can then be understood and events predicted.

For empiricists, such laws are derived through the 'empirical cycle'. In this, objective researchers collate information from observation of events in order to develop hypotheses to explain their causes. This inductive process works from effects to causes, or facts to general principles. It is assumed that events observed are factual, objective, prior to theorizing and interpretation, and that an idealized, unprejudiced mind is capable of identifying nature without error (Popper, 1970: 502). Individuals then work deductively from cause to effects, using the results of controlled experiments, manipulating proposed causes to measure effects, to verify or 'justify' the accuracy of the hypothesis' representation of ontological law.

Rationalists have inverted this aspect of empiricist process to demarcate science from non-science. For Popper, facts can never be abstracted objectively from the theoretical framework in which their observers operate. Often, it seems that 'Whatever happen[s] always confirm[s]' the framework (Popper 2002: 45; see also, Freud, 1995: 12). This is delusional, as natural processes are too elusive, and human faculties too fallible, for hypothetical laws to be verified indubitably as true (Wittgenstein, 2001: 22-23). As such, science lies methodologically, not in empirical observation but, in 'critical thinking' (Popper, 1970: 53), and theorizing in a priori commitment to logical consistency (e.g. Popper, 1970: 57) and 'falsifiability'. A good hypothesis is a 'prohibition: it forbids certain things to happen.... A theory which is not refutable by any conceivable event is non-scientific' (Popper, 2002: 48). Strength lies, not in potentially subjective empirical verification but, in the ability to withstand attempts to falsify (Popper, 2002: 345-346). This does not preclude foundationalism or the telos of truth; truth, empirical rigour and consistency are still desirable ends (Popper, 1970: 57; 289). However, the definition of science rests upon a rationalist method with emphasis upon reason and necessity of refutation.

Lakatos' 'sophisticated falsificationism' develops this position by holding frameworks to represent different aspects of the same objective realities (Lakatos 1970: 145). To be scientific, however, they must supplement prior explanations (Lakatos 1970: 142) by offering corroborated, 'excess' information (Lakatos 1970: 118). For Lakatos, 'There is no falsification before the emergence of a better theory' (Lakatos 1970: 119). Naïve falsification which, 'instead of offering a content-increasing (scientific) explanation, only offers a contentdecreasing (linguistic) reinterpretation' (Lakatos 1970: 119), is pseudoscientific. Each research programme should be measured, not by its ability to dismiss rivals but, logically and empirically, by its constructive ability to deduce 'ever more true and ever fewer false consequences' (Lakatos, 1970: 188).

The radical, and incompatible, alternative to such evaluative conclusions, is to regard schema as incommensurable, and science as a form of human knowledge bereft of ontological foundations. In Kuhn (1996) we find a philosophical rejection of Platonic/Aristotelian dualism in favour of relativism. This denotes the belief that 'truth' cannot be abstracted from socially situated human comprehension. Science itself is a culturally and historically situated construct, the methods of which are recent and relative to a particular social endeavour. There can be no unprejudiced, empiricist observer, nor Nagel's (1986) 'view from nowhere'. As such, induction is bereft of intrinsic, objective value, while "'objective truth" [is] no more and no less than the best idea we currently have about how to explain what is going on' (Rorty 1980: 385). Kuhn transcends the arguments of Popper and Lakatos to claim that, not merely are observations of events subjective, the events themselves are subjective, bereft of ontological foundations, and indivisible from the language used in their description (Popper, 1970: 56). What defines 
science, for Kuhn (1996: 205), is that, in addition to its (delusional) belief in truth, it regards 'puzzle-solving as a goal' (Kuhn 1996: 209). Scientific progress lies in the extent to which such puzzles can be solved, rather than to the ontological 'match... between the entities with which the theory populated nature and what is "really there"" (Kuhn 1996: 206). Kuhn illustrates this position by referring to 'Boyle's Law relating gas pressure to volume'. Such experiments 'were not conceivable until air was recognized as an elastic fluid to which all elaborate concepts of hydrostatics could be applied' (Kuhn 1996: 28). In constructing and solving puzzles, humans 'determine normal science without the intervention of discoverable rules' (Kuhn 1996: 46).

There are general puzzle solutions that encompass the entire category of science. However, the way in which they are pursued, interpreted and applied is heterogeneous (Kuhn 1996: 50). Sciences progress from 'pre-paradigmatic' form in which the most general and existential questions are considered, to paradigm form. In this, consensus is reached on metaphysics, interpretative theory and methodology. A shared understanding of the world is developed that 'sets the problem to be solved' (Kuhn 1996: 27), directs interpretation of events and codifies the means by which events are measured. For Kuhn, paradigms are intrinsically bereft of internal criticism (Kuhn 1996: 46-47). When deficits, inconsistencies or anomalies within the various metaphysical, methodological and practical strands of the paradigm become irreconcilable, new paradigms emerge, with new positions on metaphysics, methodology, and the validity of research areas (Kuhn 1996: 52-76). However, because paradigms rest upon fundamentally subjective perspectives on foundationless events, there can be no rationalist ranking and no empiricist verification of the truth; just an acknowledgement that each successive paradigm approaches those problems within any given field from a sociohistorically situated perspective. In this respect, the academic communities engaged in each paradigm are incommensurable, incompatible and non-cumulative, bereft of shared principles, premises or bases of truth by which to measure their success (Kuhn 1996: 199-201; 208). Contra Lakatos, paradigms do not accumulate knowledge from the previous paradigm, but regard it as incompatible and, because the research questions differ, irrelevant.

Perhaps the first psychological puzzle-solving paradigm, with circumscribed metaphysics, theory and methodology, was psychoanalysis. This discipline, and particularly its theory of the Oedipus complex, is presented by Popper as an example of psychology's pseudoscientific foundations. However, psychoanalysis did purport to operate according to empiricist and rationalist criteria. The theory, or hypothesis, of the Oedipus complex (Freud, 1995: 21-23) was derived by Freud through inductive inquiry into 'subconscious' emotions and thoughts which were often maternally erotic and paternally aggressive. Methodologically, Freud held empiricist faith in both the truth and the ability of skilled individuals to perceive and comprehend, objectively, their own emotions and, through discussion and observation of responses to psychological stimuli, to perceive and interpret accurately the thoughts and emotions of others (Freud: 172-239; Popper 2002: 46).

This enabled psychoanalysts to cite childhood development as the cause of apparently unrelated behavioural and psychological activity in adulthood. The universality of, for example, Oedipus, was refuted empirically by Malinowski's (2001) observation that the complex was absent in other cultural contexts. However, while universality is logically refutable, the notion of Oedipus itself is 'non-testable, irrefutable. There [is] no conceivable human behaviour which could contradict' (Popper 2002: 49) the theory. Although Freud 'believed that physiology would eventually explain the workings of the mental apparatus' (Skinner, 1972: 12), he did not put forward 'criteria of refutation' which, if 'observed, mean that the theory is refuted'. Despite his claim that 'the speculative superstructure of psychoanalysis... can be abandoned... without... regret the moment its inadequacy has been proved' (Freud, 1995: 20), there are numerous 'analytical concepts, such as "ambivalence"" that 'make it difficult... to agree upon' criteria of refutation (Popper 2002: 49n3). Although 
Freud envisaged his methods as advancing prior physiological research, many of his speculative theories merely contradict, rather than build upon, prior that work, amounting to naïve falsification without falsifiable construction (Freud, 1995: 14-15). However, empirical and logical deficits do not, necessarily, detract from psychoanalysis' puzzle-solving endeavours. If theories solve self-constructed puzzles, and are regarded internally as true, they constitute, for Kuhn, an incommensurable scientific paradigm.

The quandaries faced by policy makers engaged in advancing the interests of any country, not least the United States, are, in one sense, similar to those of scientists such as Freud. However, political paradigms have real impacts on human beings. Their solving selfconstructed puzzles may be irrelevant if the consequences, as in the Global Financial Crisis or the War on Terror, constitute human misery. At some basic level, refutation is valuable precisely because the consequences of approaches' being 'wrong' are so serious. All too often, though, paradigms have actively resisted refutation.

This has long been a critique of teleological forms of Marxism. Žižek (2013), for example, challenges 'the naïve defence of the purity of the concept' in which proponents hold that, if things go wrong with building a socialist society, this does not invalidate the idea itself, it simply means we didn't implement it properly'. As Johnson and Mabon $(2018,202)$ argue, proponents often believe that, 'Were Marxian tenets applied purely, they would lead humanity to a perfected condition'. There are parallels analytically with Oedipus, but the consequences extend beyond perpetuation of questionable forms of therapy. Precisely because of the amorphous nature of the conditions under which a phenomenon is studied and the radical diversity of variables, such as 'false consciousness', at play, proponents of paradigms have means of avoiding refutation of the approach itself. This is why falsification, in particular, matters when evaluating the contributions of social 'science' to policy. Although a paradigm may have much to commend it by virtue of its empirical value in capturing elements of the human condition or its ability to solve puzzles - and blaming the conditions under which an approach is tested for its inability to control variables is surely an impressive means of dealing with the puzzle of failure -, the practice of politics itself, and foreign policy in particular, requires means of dealing with variables as they exist.

Both Žižek and Johnson and Mabon argue that unfalsifiability is a hallmark of fundamentalism and cite a number of examples of such doctrines, including those inspired by messianic religious thinking, which respond to narrative challenges by advancing ever purer applications of ideas, rather than revision of tenets. At a basic level, those approaches are of limited value in dealing with myriad challenges, particularly in foreign policy, because they need to shape humans in particular ways in order for their prescriptions, universally, to work if, indeed, they ever can. In order to address the crises of the new millennium, there is good reason to hold paradigms to criteria of refutation that permit us to establish their value within particular contexts. The particular context with which we wish to grapple is American Empire, since this is one that, in the context of the Trump Presidency, is of primary importance both within and without the US. To do this, we need to understand the ways in which understandings of empire have emerged in American discourse.

\section{The emergence of empire in American discourse}

The concept of 'empire' had been invoked by American writers long before independence from Britain (Hopkins 2018; Immerman 2010; Maier 2006). In such cases, 'empire' did not signify a geopolitical realm but was instead interchangeable with 'dominion' and synonymous with 'power' or 'sovereignty', in a continuation of the imperial discourse which British (and more broadly, European) political philosophy had adopted from Christian dominionism and Byzantine/Habsburg imaginations of universal monarchy, formulated in the Middle Ages (see Greene 1986: 91-104). As a result, in the early modern period 'empire' lacked the negative 
connotations acquired in the later eighteenth and early nineteenth centuries in response to European exploitation (Muthu 2003), resulting in American colonists objecting to the term 'colony', but not to 'empire' (Greene 1986: 101). Empire was viewed, then, not as anathema to democracy and liberty but as a companion and vehicle through which these ideals might be maintained (Maier 2006: 2-12). This was enhanced by the increasing adoption, in eighteenthcentury colonial discourses, of the imagination of Republican Rome and the nexus between popular sovereignty and state power (Hingley 2001). An early commentator on sovereign jurisdiction in the rapidly distancing American colonies, William Blackstone (cited in Greene 1986: 101-102) summarized 'empire' as 'a supreme, irresistible, absolute uncontrolled authority, in which the jura summi imperii, or the rights of sovereignty, reside'. In this regard, 'American Empire' as a set of higher, universal ideas was 'a commitment that had no territorial or political boundaries' (Tucker and Hendrikson 1990: 160).

This conception of 'empire' as an expression of newfound sovereign power was most famously invoked by Thomas Jefferson, who repeatedly underlined the theme in his political catechism 'Empire of Liberty'. This discourse culminated in 1809 with his declaration that 'I am persuaded no constitution was ever before as well-calculated as ours, for extending extensive empire and self-government' (cited in Panitch and Gindin 2004: 26). This understanding was echoed by one of the first propagandists of the Jeffersonian imperial vision, Hugh Henry Breckenridge (cited in Maier 2007: 1), who addressed his fellow Americans thus: 'You are now citizens of a new empire: an empire, not the effect of chance, not hewn out by the sword; but formed from the skill of sages, and the design of wise men.... You have acquired superior strength; you are become a great people'. The 'infant empire' to which George Washington referred (cited in Ferguson 2003: 34), expanded west, eventually absorbing the immense landmass previously dismissed as undesirable by the Atlantic-oriented British. This 'overland expansion', as Ferguson (2003: 35) puts it, 'was easy... [;] the Native American populations were too small and technologically backward to offer more than sporadic and ineffectual resistance'. In seeking new land to till and opportunities to exploit, ever increasing numbers of settlers fleeing oppression in the Old World drove expansion both geographically and ideologically, pushing forward 'a frontier of liberty' (Hardt and Negri 2000: 169). This secular dominion encouraged a prevailing belief in the US that America constituted an exception to European political norms. America was instead imagined to be what John Winthrop described in 1630 (citing Matthew 5:14) as the 'City on a Hill' (Greene 1986: 7); America and its fledgling empire were exceptional to, and not a continuation of, European motives for empire-building.

Expansion by a republican society that had overthrown monarchy has produced inevitable comparisons with Rome. Leo Panitch and Sim Gindin (2006) caution that the very use of the word 'empire' has been used as means of drawing spurious analogies between the two civilizations in order to lament or cheer America's ascendancy or decline. This concern is shared by the ideologically opposed Joseph Nye (2016), who devotes an entire chapter to deconstructing lazy equations of two societies which share little more than superficial similarities. While imperial analogies for the contemporary United States have been over-used, it is undeniable that Roman civilization - the imagination of Rome rather than its reality - was a significant influence upon American political self-perceptions. Antagonism between British and Americans, and between Americans in the decades before 1776, was overwhelmingly framed by references to Republican Rome, its foundational philosophical commitments and attendant account of institutions and political rights and responsibilities (Kramnick 1987: 7677). In advance of the Revolution, Americans often grounded calls for independence in the works of Cicero (Hingley 2001). After independence, discussions of how to structure the new society, such as those fostered by the Federalist Papers (Kramnick 1987) and the AntiFederalist Papers (Ketcham 1986), were again dominated by lessons drawn from Rome. 
Particularly prominent in this is Cicero's notion of Rome as benign protector (patrocinium), not as conqueror (imperium), of civilization (see the introductions to Grant 1998). Long before independence, and accelerating afterwards, imaginations of empire-as-guardian rather than empire-as-conqueror cast a long shadow over the nascent US' account of itself (see especially Schiavone 2000; Hingley 2001; Ward-Perkins 2005) - a view indigenous Americans, among others, would regard with understandable bemusement.

The notion of the 'Manifest Destiny' of US expansion across the continent was supported by the distinction in Jeffersonian 'empire of liberty' between political means and philosophical ends (see Greene 1986). In this conception, empire (or union) was simply the political means of upholding negative liberty in the Lockean tradition (Armitage in Muthu 2012) - an end regarded as value to any rational individual (Tucker and Hendrikson 1990). As Boyd (cited in Tucker and Hendrikson 1990: 159) put it, the

Empire of Liberty... was to be neither an isolated political entity nor an imperialistic force for compulsory extension of ideals of liberty: its domains and compulsions would be in the realm of the mind and spirit of man, freely and inexorably transcending political boundaries, incapable of being restrained, and holding imperial sway not by arms or political power but by sheer majesty of ideas and ideals.

The continental polity that emerged from this imperial dynamic deployed a form of delegated and partially democratic 'imperialism'. The federal state system allowed new areas of settlement to reproduce the Jeffersonian federalist model of decentralized government and semi-autonomous commonwealths exercising rights of supreme dominion while simultaneously replacing inefficient, centralized and distant, British-style imperialism with effective self-administration within states (Panitch and Gindin 2004: 27). In this regard, American empire was founded on what might be termed 'Network Power'; 'a democratic interaction of powers linked together in networks... [;] the constitutional formation of limits and equilibria, checks and balances, which both constitutes a central power and maintains power in the hands of the multitude' (Hardt and Negri 2000: 161).

Such self-understandings of early American empire are reproduced in a number of paradigmatic narratives. However, particularly from 1945 onwards, analyses of American empire depart in interesting ways (Doyle 1986). In what follows, we trace the ways in which two key paradigmatic analyses - neoconservatism and neoliberalism - have narrated American empire and responded to the challenges posed to the US over the past decade or so since the geographical scope for expansion was tested by the emerging failures of intervention in Afghanistan and Iraq, the economic scope by the Financial Crisis, and the political scope by the Trump Presidency. While the approaches are distinct and view contemporary US politics in very different ways, they share an ideological commitment to elements of classical liberalism and belief in the promotion of associated American values overseas.

\section{Neoconservative 'doubling down': democracy and/or unipolarity as a choice}

While most clearly associated with G. W. Bush's Presidency, neoconservatism emerged paradigmatically from the work of a body of US liberals disillusioned by the reluctance of Democrats to assert liberalism forcefully. From 1945 (see Cooper 2011: 24-46), but especially the 1960s, onwards, thinkers increasingly produced 'a peculiar synthesis of realism and idealism' (Drolet 2010: 89) that asserted the unique, transhistorical value of American democracy (Halper and Clarke 2004: 76-81; Dorrien 2004: 75-122) and the need to uphold it within a subversive, hostile world, through hard power and expansion (Dorrien 2004: 7-26). By the turn of the $21^{\text {st }}$ Century, such 'liberals in wolves' clothing' (Betts in Caverley 2013: 145) included Paul Wolfowitz, William Kristol, Robert Kagan, and Charles Krauthammer 
(Dorrien 2004: 27-34, 75-180; Halper and Clarke 2004: 112-156; Vaïsse 2010: 220-270). Their work came to influence the actions of the US and its allies, not just in attacking states, nonstate actors (such as transnational terrorist groups) and ideologies (Halper and Clarke 2004: 273-295) deemed inimical to liberalism, but in asserting a democracy-in-all-policies approach that regarded representative democracy as the foundation of all other goods. As Joshua Muravchik (1991 in Cooper 2011: 89) put it, 'democracy has proved itself natural' (Muravchik 1991 in Cooper 2011: 89) and, as 'our creed', 'we are prepared to do what we can to help others achieve it' (Muravchik 1991 in Dorrien 2004: 77).

Enjoined by concern for Jeffersonian empire of liberty (Dorrien 2004: 35), they have long upheld what the Kristols describe as 'global unilateralism in the moral arena' (Dorrien 2004: 83). These fundamental commitments persisted through what Krauthammer termed the Reagan Doctrine (Halper and Clarke 2004: 217-221) and were presented as reasons for America's emergence as the global superpower in the 1990s (Ryan 2010a). The context of the Cold War and then Islamist opposition to the US granted neoconservatism what Vasquez (1997: 899-912) terms 'fertility' in its development (see also Ryan 2010b; Vaïsse 2010), with belief in zero-sum competition providing evolving binary opposites against which to forge democracy promotion in foreign policy. This is apparent in the consistency with which neoconservatives, such as Robert Kagan, Paul Wolfowitz, and William Kristol have followed 'Irving Kristol, neoconservatism's godfather' (Immerman 2010: 209), in believing in the enduring need for the US unilaterially to preserve Pax Americana (Glasser 2017; Wolfowitz 2017): 'Destroying monsters was the prerequisite for establishing an American empire, and an American empire was the prerequisite for an Empire of Liberty' (Immerman 2010: 221).

There is, though, debate about the extent to which democracy, rather than American unipolarity, is, in any substantive sense, the key foundational value in neoconservative thought (see Caverly 2013). Maria Ryan (2010a; 2010b), for example, has highlighted the ways in which neoconservative discussion of democracy and American unipolarity is circular and preference for one or the other unclear. Neoconservatives often assert the foundational importance of American unipolarity, but also appear to suggest that the value of democracy stems from its American character. In this regard, the conceptualization of democracy is deficient insofar as liberal representative democracy has long been advanced as a neutral means of individuals pursuing interests peacefully. In its classical liberal formulation, it does not and ought not advance any particular way of life. However, noconservative justification for democracy promotion often alludes to social engineering in ways that are prima facie illiberal. The overthrowing of tyrannical regimes, such as the Soviet Union and Saddam's Iraq, has often been presented as a means of freeing individuals from preferences and 'false consciousness' that are ultimately at odds with their real interests. In that regard, their liberalism appears grounded more in concern for positive, than negative, forms of liberty (see distinction in Berlin 1969), albeit pursued through imposition of limited forms of government. Indeed, there is clearly a teleological element that runs parallel to Fukuyama's (1992) End of History thesis and which encourages an assumption that, in the wake of Soviet collapse, the US has a moral imperative to forcefully expand democracy (see Dorrien 2004: 86; Rachman 2011: 99-105; Cooper 2011: 89-91) in ways that are alien to deontic liberals, like Rawls, and which indicate forms of social engineering at odds with conservative intuitions. The fact that a significant number of neoconservatives advocate such a position (see, among others, the historiographies of Pan and Turner 2017; Ryan 2010a, 2010b; Drolet 2010; High 2009), but eschew the rhetoric of US-as-empire suggests awareness of the cultural contrast between empire and liberty.

The radical, revolutionary implications of the approach are apparent in a key strain of neoconservative foreign policy response to key seismic events. Neoconservatives have, at least, acknowledged 'the return of history' (Kagan 2008, also 2012) in the emergence of multipolarity (see Krauthammer in Halper and Clarke 2004: 220-282) 'the American Crisis' 
(Rachman 2011: 179) and the possibility of a cycle of decline. The possibility of decline has been identified across various paradigms: Robert Gilpin, David Calleo, Paul Kennedy and Robert Keohane have each claimed to have identified the symptoms of decline as early as the 1980s (Lundestad 2012: 4-5), while Nye (2017: 1-9; 18-22) details narratives of American decline visible among the Puritans. Non-neoconservative accounts of declinism assert that the post-1945 world order is no longer functioning, and that internationalism has failed beyond the point that it can be resurrected (Ikenberry 2018). Conservative historians, such as Niall Ferguson (2003; 2005) and Max Boot (Rachman 2011: 168, 274) have presented a series of policy positions that acknowledge and seek to manage American decline as part of a translatio imperii in which imperial predominance passes inevitably and cyclically from one society to the next (in this case, China), while Layne (2018), among others, has argued that a new order will be dependent on Beijing's commitment to creating an alternative to US-led interventionist institutionalism.

In contrast to analyses that recognize changing events on the ground, even those neoconservatives who acknowledge the possibility of decline have suggested that some such historical analyses exaggerate American agency in the past and underestimate it in the present. As Kagan (2012: 110) argues

Many of today's impressions about declining American influence are based on a nostalgic fallacy that there was ever a time when the United States could shape the whole world to suit its desires... This image of the past is an illusion. There was never such a time.

Vitally, those who acknowledge the possibility of decline, such as Wolfowitz, reject fatalism, arguing that the United States, although in an apparently perpetual twilight, is nevertheless the last legitimate and capable guardian of liberal values (Immerman 2010: 201-202) and can arrest that decline through ever greater application of imperial hard power (Kagan 2018; Wolfowitz 2017). While the events of $9 / 11$ radically altered the views of several key neoconservatives in the Project for the New American Century (PNAC) and its successor, the Foreign Policy Initiative (FPI), for Wolfowitz, 'the terrorist attacks on the World Trade Center and the Pentagon were akin to a self-fulfilling prophecy': 'To ensure liberty for all, America must destroy liberty's enemies' (in Immerman 2010: 223-224). In contrast to non-neoconservative peers who asserted $9 / 11$ as the consequence of, and cause for, a misguided foreign policy., Wolfowitz advocacy for the invasion (but not occupation) of Iraq in 2003 not only ended his political career but tarnished neoconservative theory to the point that few, even Wolfowitz himself, explicitly identify with the paradigm (Immerman 2010, Glasser 2017). While he regards Trump's ad hoc and inconsistent foreign policy as inferior to the unipolarity and expansionist geostrategy of the Bush era, Wolfowitz (2019; 2018a; 2018b; 2017a; 2017b) nevertheless deems a Western, US-led hegemony as preferable to isolationism and concomitant rise of humanitarian disasters, human rights violations and rival superpowers. As Kagan (2012: 134) puts it, 'Decline, as Charles Krauthammer has observed, is a choice. It is not an inevitable fate', and the US retains scope for advancement of human interests through ever greater deployment of force, even under Presidencies that have tenuous commitments to democratic process.

In one sense, this relationship between goods, narrative of history and policy prescription would appear to be the basis for falsifiability. Fukuyama, himself associated with neoconservative positions (see Dorrien 2004: 15), notes that the US 'failed to anticipate the requirements for pacifying and reconstructing Iraq, and was wildly over-optimistic in its assessment of the ease with which large-scale social engineering could be accomplished' (2006: 6-7). The US deployed hard power to overthrow a tyrant and impose representative 
democracy. The outcome was the creation of a political system riven by sectarian conflict and an undermining of US primacy and unipolarity. The fall of Wolfowitz and others from positions of influence and the dissolution of the PNAC in 2006 and the FPI in 2017 suggests popular belief in falsification of the paradigm.

However, the fact that the likes of Wolfowitz can argue that the failures were due to insufficient, rather than excessive, deployment of hard power indicates difficulty in falsifying the paradigm. Indeed, the paradigm is particularly elusive in this regard precisely because its account of its own foundational value commitments is so opaque and insubstantive. The dearth of substantive examination of the constituent features of democracy and its relationship to other human interests is indicated by the ambivalence, or even hostility, of individuals in societies subject to American imperial hard power. Again, neoconservatives avoid falsification by asserting that preferences advanced under conditions of tyranny do not correspond to real or objective interests. In that regard, the paradigm shares narrative elements of teleology, via Fukuyama, and an ethical commitment to positive liberty that its proponents criticize in Marxism. The fact that the chaos of the contemporary Middle East does not shake the faith of some neoconservatives suggests that it is an approach that brings with it the danger of military catastrophe.

In similar ways, neoliberalism has proven itself capable of dismissing evidence of the failure of its institutions in ways that lead to prescription of ever purer application of market principles.

\section{Neoliberalism: imperial soft power}

Whereas neoconservatism's focus lies on promotion of democracy, often through military means, a popular strand of neoliberalism has, since the 1990s, advanced the importance of American cultural hegemony and the value of capital to US interests. As with neoconservatives, Joseph Nye is wary of using 'empire', partly because the word implies empire-by-coercion rather than empire-by-consent, and partly because invoking the words 'American Empire' encourages media-friendly, but academically deficient, comparisons between the US and Imperial Rome (Nye 2016: 71-73). In contrast to neoconservatism, however, there is a much more thoroughgoing concern for American liberalism as a complex whole. Liberalism and, its ability to foster cooperation and interdependence through the market, grants American culture unique, transhistorical value to human beings insofar as it is able to draw radically divergent individuals into a single social sphere.

This is because American liberalism's capacity to construct resilient institutions enables rational, self-interested individuals to pursue their interests efficiently and peacefully. In this view, 'institutions as agreements or contracts between actors that reduce uncertainty, lower transaction costs, and solve collective-action problems' (Grieco and Ikenberry 2003: 116). It is this that grants 'The United States... a universalistic culture' (Nye 2004a: 11). Although there are parallels with neoconservative concern for demcoracy, neoliberalism more clearly upholds the notion of liberalism as a procedural framework through which individuals pursue their interests without that framework promoting any one particular conception of the good. Indeed, whereas neoconservatism refers crudely to democracy as a foundational value, neoliberalism upholds a much broader set of institutional arrangements converging upon protection of negative liberty, private property and the market. Liberalism not only upholds the interests of individuals within a given society, it grants societies with similar liberal institutional commitments the capacity to cooperate. The clearest historical articulation of this position comes from President Wilson, whose neo-Kantian doctrine holds that coexistence and cooperation with states can only occur if those states live according to liberal, international law (see Doyle 1986: 81-82; 285). Wilson, in his 'Fourteen Points', advocated 'a general association of nations... to afford mutual guarantees of political independence and territorial 
integrity to all states' (Wilson 1918). As a consequence, and in keeping with Cicero's and Jefferson's accounts of patrocinial empire of liberty, neoliberals have become committed to spreading the 'liberal state' through intervention as the key 'foreign policy imperative' (Cooper 2002: 177).

In sharp contrast to neoconservatism's concern for hard power, however, Nye's neoliberal institutionalism focuses on 'soft power': 'the ability to get what you want through attraction rather than coercion or payments... [arising] from the attractiveness of a country's culture, political ideals, and policies' (Nye 2004a, x). In the aftermath of World War II and facing competition from the Soviet Union, it was clear to European and American observers that industrialized democratic allies required a centralized power to sustain and supervise their embedded liberal institutions (Nye 2004a: 39). America's imperial primacy was far from inevitable, but the US proved the only power with an existing philosophical project and moral legitimacy for overseeing informal empire. The success of this 'empire by invitation' (Gordon and Shapiro 2004: 196) was demonstrated by the integration of the former Axis core, Germany and Japan (see Ferguson 2003: 68; Brzezinski 1997: 25; Todd 2001: 61). By virtue of cooptation, Nye (2004a: 136) is clear that 'The United States is certainly not an empire in the way we think of the European overseas empires of the nineteenth and twentieth centuries because the core feature of such imperialism was direct political control'. In effect, the focus of imperialism shifted from European style-colonialism of non-Western states corralled into an unequal power relationship, to a new informal/hegemonic arrangement between developed societies sharing (theoretical) equality within 'the voluntary imperialism of the global economy' (Cooper 2002: 18).

Increasingly, and in keeping with Marxist accounts, the 'cultural export' (Todd 2001: 63) of free trade in its subject states enabled the US to penetrate once isolated societies. Fordist capitalism enabled mass consumption of American-style goods and media (Nye 2004a: 11), drawing those in the informal empire towards the US and its liberalism through the superiority of its goods in an increasingly global cultural market. These US-developed consumer societies ensured that economies, people and culture become intertwined and mutually dependent in relationships of patrons and clients, rather than conquerors and subjects. For neoliberals, American soft power is a potent foreign policy force precisely because it is not spread through force of arms - it appeals and attracts (Nye 2016). It is seen as having 'a crucial role to play in promoting democracy, human rights, and open markets' for 'It is easier to attract people to democracy than to coerce them to be democratic' (Nye 2004a: 17).

Like neoconservatives, neoliberals retain belief that tyrannical societies suppress individuals' interests and are increasingly aware of the ways in which the damage caused by the War on Terror and Great Recession have undermined unipolarity. While Nye has called for the US to 'define [its] national interest to include global interests' (Nye 2002: xiv), there has been an enduring pessimism toward the kind of hard power expansionism favoured by neoconservatives in Iraq and Afghanistan. This is because neoliberals retain faith in the unique capacity of American cultural capital to promote US position of strength (Nye 2016) even as its hard power wanes (Nye 2004b).

Indeed, as Charles Kupchan's post-Great Recession work (2013) demonstrates, neoliberal commitment to institutions means that they reject neoconservative zero-sum approaches to great power politics and the notion that the US's decline is the inevitable consequence (and cause) of China's rise. This is apparent in Kupchan's (2018) attempt to advance praxis-oriented reforms to enable post-Trump governments to reinforce civil solidarity and social integration and boost the economic power of ordinary citizens. Going beyond crude neoconservative analyses of American democracy, his approach recognizes the possibility of inequalities of power within capitalist societies undermining citizens' interests. In seeking to repair American liberalism, he seeks to renew its global appeal, advancing a geopolitical 
balance between the disinterested isolationism of pre-Pearl Harbor 'American Exceptionalism 1.0' and the imperial overreach of post-1945 'American Exceptionalism 2.0'.

However, he, like Nye, sees no evidence in recent seismic events to falsify neoliberal claims and none of his policy suggestions constitute a paradigmatic shift. The fact that neoliberals advance tweaks to the present institutional framework, rather than dispensing with it, stems from faith in the notion that the US, as the society most keenly attuned to liberalism, will retain its power by virtue of its intrinsic features, even as it comes to accommodations with emerging industrial powers. In this regard, Nye (2017: 4) states that 'economic power alone should not be used' as a means of evaluating US status in the world. Contrary to the zero-sum geopolitical rivalry of neoconservative accounts, Nye (2016: 23-45) acknowledges that the US requires allies but is now more able than before to act without fear of rivals.

The soft (and hard) power of Japan, the EU, and the BRICS is negligible. Russia lacks any kind of grand strategy for recovery and simply reacts opportunistically to world events (Nye 2016: 35). India is too severely split between a spacefaring elite and a multiethnic society living in poverty (2016: 38-41) while Brazil and South Africa are severely underdeveloped and mired in corruption. In contrast to Arrighi's (2005) belief in the coming Chinese Century, Nye perceives a China inherently incapable of challenging the US on a global level. While China has the capacity to become a regional power and push US interests out of mainland East Asia and the ASEAN nations (Nye 2017: 68-70), Beijing will never achieve parity with Washington in the contest for soft power supremacy. Chinese conventional military forces are on technological parity with, and significantly larger than, the US military, but China's forces lack anything approximating the global presence of the Americans who possess what Fattor (2014) calls 'an arsenal of entertainment'. Furthermore, Nye (2016) argues that the Chinese government - what David Shambaugh (in Sullivan 2018: 17) calls 'a partial power' - lacks any motivation for changing the neoliberal world order or pursuing global hegemony. While a statecentric model is significantly more effective in promoting industrialization and development within a country, state-sponsored trade is ineffective in expanding soft-power influence beyond the nation's borders and immediate neighbours. It is incapable of overcoming the decades old American private and public commercial, educational, religious, political and military institutions by which the US has achieved influence throughout an increasingly Anglophonic world (Nye 2016). Instead of challenging the neoliberal paradigm, there is a sense that neoliberalism will continue to benefit both China (and, by extension, the BRICS) and the US, with America in a position of primacy (Sullivan 2018).

In keeping with teleological accounts of change in historical Marxism and elements of neoconservatism, such analyses stem from belief that international neoliberal institutions have the capacity to ensure that, as those societies become institutionalized, they become more like America itself. Societies face an implausible choice between 'the old Western liberal pathway' and authoritarianism (Ikenberry 2013: 91-93). In effect, alternatives to liberalism simply demonstrate its enduring value and confirm that the model needs simply to be tweaked and reapplied with greater effort. This position is evident in Deudney and Ikenberry's (2018: 18) claim that 'the remedy for the problems of liberal democracy is more liberal democracy; liberalism contains the seeds of its own salvation' and Ikenberry's (2013: 92) emphatic statement that

Yes, the American liberal hegemonic order is in crisis. But it is a crisis of authority within the liberal international order and not a crisis of its underlying principles and organizational logic. That is, it is a crisis of the American governance of liberal order and not of liberal order itself [emphasis added]

As such, just as neoconservatives argue that the solution to the failings of American hard-power 
is more hard-power, neoliberals argue that the solution to the failings of soft-power is more soft-power through the entrenchment of liberal institutions.

The parallel to neoconservatism's 'doubling-down' stands in contrast to a growing body of evidence that casts doubt on liberalism's viability (Friedman, Oskanian and Pardo 2013). Challenges to the postwar liberal order are not dismissed as insignificant or trivial, but neither are they seen as indicators that the system or its framing paradigm are in need of substantial revision. The US may lack the raw power and self-confidence of the 1945-2001 imperial 'golden age', but neoliberals remain convinced that American primacy can be sustained through reform and revision (Nye 2015) led by a strong American hand itself (see Ikenberry 2018; 2013). This is even evident in neoliberal responses to the apparent disregard for institutions in the Trump Presidency. As Sullivan (2018: 14) puts it, 'Trump has found that whatever his contempt for the rules-based order, he needs it' (Sullivan 2018: 14). Likewise, although Nye (2016: 126) emphasizes that 'leadership is not the same as domination' and in spite of an erratic and unpredictable administration characterized by a 'cavalier [attitude] about the threat of force' (Posen 2018: 26), the Paris climate accords, the Vaccine Alliance (Sullivan 2018) and the Trans-Pacific Partnership, among other agreements, all indicate a need among other states for US interventionism and internationalism.

In this regard, neoliberalism appears to fall, with some difference in conceptualization of values and power, into the same unfalsifiable thinking as neoconservatism: its values are of transhistorical, universal, objective importance; they explain US emergence as an imperial power; American institutions that uphold those values exist in a hostile context in which the alternative is tyranny; any downturn in American primacy is explicable through reference to imperfect application of neoliberal institutionalist policy and that the only option available to policy makers is a doubling down on expansionist liberalism. There appear few seismic events that falsify neoliberal policy.

However, there is a rejoinder: while Nye is fervent in his belief in the sustainability of American primacy, he acknowledged, before the 2016 Presidential Election, that 'deterioration of American social conditions could also reduce soft power', arguing that 'Culture wars could adversely affect American power if citizens become so distracted or divided by domestic battles over social and cultural issues that the United States loses the capacity to act collectively in foreign policy' (Nye 2016: 73-74). Moreover, Nye (2016: 82) anticipates the concerns of both Niall Ferguson and Nigel Hamilton (2017: 26) about US debt negatively influencing power projection. In the event of American institutions becoming gridlocked or public trust in American institutions dwindling rapidly (Nye 2016: 88), American power will weaken. Internal social problems in the USA which, since the Trump inauguration, have been exacerbating social fragmentation and a lack of trust in the social order and government, may confirm these fears (Hamilton 2017) but only in the short term. However, even while acknowledging their effects, the likes of Nye and Posen (2018) retain faith in American primacy, while Norrlof (2018) argues that social reforms to defuse the racism implicit in Trump's '(white) America First' agenda can in fact return America's primacy and leadership of the liberal international order, rather than merely sustaining the US as one of several equivalent states

Were the paradigm falsifiable, neoliberals would have reason to reject support for the institutions that gave rise to the Financial Crisis, the costs of austerity policies and the rise of demagogic leaders. Neoliberal belief that the only plausible response to such crises is greater neoliberal institutionalism looks faith-based. As such, like neoconservatives, neoliberals believe, fundamentally, in authenticity of praxis, in which failings of their institutions are attributed, not to their core commitments, but to insufficient purity of application. The problem, as Žižek (2013) notes, is that 'When we dismiss the failures of market capitalism as accidental mishaps, we end up in a naive "progress-ism" that sees the solution as a more "authentic" and 
pure application of a notion, and thus tries to put out the fire by pouring oil on it'. As such, where neoconservative policies run the risk of compounding military failure, neoliberal policies run the risk of compounding social failures of capital.

\section{Conclusion: the need for falsifiability}

Writing before the invasion of Iraq in 2003, Mark Hertsgaard (2002: 80) believed that America's unacknowledged, 'oblivious empire' - what Charles Maier (2003, in Ferguson $2005,16)$ called 'an empire that dare not speak its name' - demonstrates 'no signs or either shrinking... or retreating'. This is no longer the case (Bacevich 2017). However, the leading paradigmatic accounts of American empire above indicate dogma in the face of prima facie confounding events that may stem from shared intellectual commitments to elements of classical liberalism. That approaches should be able to accommodate the otherwise unforeseen events within their narratives indicates a level of unfalsifiability.

Interestingly, whether accepted by Marxists themselves or not, the dissolution of the Soviet Union was taken as evidence by which to refute belief in the inevitability of historical progress towards communism. The consequence was that countries were no longer informed by Marxist analyses. As such, in effect, Marxism proved much more falsifiable (albeit by means inferred by critics) than the two approaches above. Indeed, the very fact that contemporary Marxists often eschew teleological approaches only supports this assertion. While neoconservatism has suffered a similar fate in light of hard-power foreign policy failures under Bush and Obama, neoliberalism's survival is both remarkable and concerning. A comforting self-assurance pervades much contemporary neoliberal discourse, with the Carnegie Endowment for National Peace dismissing President Trump's erratic foreign policy and the apparent demise of the postwar liberal order as a 'blip' to be overcome by redoubling neoliberal praxis (Sullivan 2018: 10). This reluctance to engage with reality is not just of academic relevance - it can lead to precisely the sort of crises that neoliberalism claims to fix. Having to provide criteria of refutation would, at the very least, grant policy makers the ability to assess the risks of policies being pursued to their logical conclusions. For pragmatic reasons alone, those paradigms that refuse to provide such criteria ought to be dismissed as fundamentalists incapable of informing constructive policy.

Statement of interest: On behalf of all authors, the corresponding author states that there is no conflict of interest

\section{References}

Allison, G. and Ferguson, N. (2016) 'Why the US President Needs a Council of Historians'. The Atlantic, September 2016. https://www.theatlantic.com/magazine/archive/2016/09/dont-know-much-abouthistory/492746/ [Accessed 5 September 2019].

Arrighi, G. (2005) 'Hegemony Unravelling'. New Left Review 32, pp. 23-80. http://www.newstatesman.com/2013/10/americans-abroad [Accessed 6 October 2017].

Bacevich, A. (2017) 'Saving "America First”'. Foreign Affairs 96:5, 57-67.

Berlin, I. (2002) 'Two Concepts of Liberty', in I. Berlin, Liberty, Oxford: Oxford University Press, pp. 166-218.

Brzezinski, Z. (1997) The Grand Chessboard. New York: Basic.

Cahill, D. (2017) The End of Laissez-Faire. London: Edward Elgar.

Caverley, J. (2013) 'Neoconservatism, Neoclassical Realism, and the Narcissism of Small Differences', in Friedman, R., Oskanian, K. and Pardo, Ramon Pacheco (eds.) (2013) After Liberalism?. Basingstoke: Palgrave, 145-166.

Cooper, R. (2002) 'The Post-Modern State'. In, M. Leonard, ed., Re-Ordering the World, 
London: Foreign Policy Centre, pp. 11-20.

Cooper, D. (2011) Neoconservatism and American Foreign Policy. London: Routledge.

Deudney, D. and Ikenberry, G. John (2018) 'Liberal World'. Foreign Affairs, 97:4, $<$ https://www.foreignaffairs.com/articles/world/2018-06-14/liberal-world> [Accessed 6 September 2019].

Dorrien, G. (2004) Imperial Designs. London: Routledge.

Doyle, M. (1986) Empires. Ithaca, NY: Cornell University Press.

Drolet, JF. (2010) 'A liberalism betrayed?'. Journal of Political Ideologies, 15:2, 89-118.

Fattor, E. (2014) American Empire and the Arsenal of Entertainment. Basingstoke: Palgrave.

Ferguson, N. (2003) Colossus. London: Penguin.

Ferguson, N. (2017a) 'Donald Trump's New World Order'. NiallFerguson.com 11 September. http://www.niallferguson.com/journalism/politics/donald-trumps-new-world-order [Accessed 6 October 2017].

Ferguson, M. (2017b) 'Donald Trump begins to dangle on the imperial hook'. NiallFerguson.com 27 August. http://www.niallferguson.com/journalism/politics/donald-trump-begins-to-dangle-onthe-imperial-hook [Accessed 6 October 2017].

Foster, R., Megoran, N. and Dunn, M. (2017) 'Towards a Geopolitics of Atheism'. Political Geography 60, 179-189.

Freud, S. (Gay, P., ed.) (1995). The Freud reader. London: Vintage.

Fukuyama, F. (1992) The End of History and the Last Man, London: Penguin.

Fukuyama, F. (2006) After the Neocons. London: Profile.

Glasser, S. (2017) 'Why Paul Wolfowitz Is Optimistic About Trump'. Politico, 24 April. http://www.politico.com/magazine/story/2017/04/24/paul-wolfowitz-donald-trumpiraq-middle-east-215065 [Accessed 6 October 2017].

Gordon, P. H. and Shapiro, J. (2004) Allies at War. New York: McGraw-Hill.

Grant, M. (1998) Cicero: Selected Works. Oxford: Oxford University Press.

Greene, J. (1986) Peripheries and Centre. Athens, GA: University of Georgia Press.

Grieco, J. M. and Ikenberry, G. J. (2003) State Power and World Markets. New York: W.W. Norton \& Co.

Halper, S. and Clarke, J. (2004) America Alone. Cambridge: University of Cambridge Press.

Hamilton, N. (2017) 'The decline of the American empire... and the crumbling of world order'. New Statesman 31 August. https://www.newstatesman.com/2017-08-31 [Accessed 6 October 2017].

Hardt, M. and Negri, A. (2001) Empire. Cambridge, Mass: Harvard University Press.

Hertsgaard, M. (2002) The Eagle's Shadow. London: Bloomsbury.

High, B. (2009) 'The Recent Historiography of American Conservatism'. The Historical Journal 52:2, 475-491.

Hingley, R. (2001) Roman Officers and English Gentlemen. London: Routledge.

Hopkins, A. G. (2018) 'American Empire'. Princeton, NJ: Princeton University Press.

Ikenberry, G. J. (2018) 'The end of liberal international order', International Affairs 94:1, pp. 7-24.

Ikenberry, G. J. (2013) 'The Liberal International Order and its Discontents', in Friedman, R., Oskanian, K. and Pardo, Ramon Pacheco (eds.) (2013) After Liberalism?. Basingstoke: Palgrave, pp. 91-102.

Immerman, R. (2010) Empire for Liberty. Princeton, NJ: Princeton University Press.

Johnson, C. (2004) The Sorrows of Empire. London: Verso.

Johnson, M. and Mabon, S. (2018) ': examining the role of public reason in "non-liberal" approaches to "unreasonable" doctrines', Australian Journal of Political Science, 53:2, pp. 195-210. https://doi.org/10.1080/10361146.2018.1447548. 
Kagan, R. (2019) The Jungle Grows Back. London: Penguin Randomhouse.

Kagan, R. (2012) The World America Made. New York, NY: Alfred Knopf.

Kagan, R. (2008) The Return of History and the End of Dreams. London: Atlantic.

Kagan, R. (2003) Paradise and Power. London: Atlantic.

Kaplan, L. and Kristol, W. (2003) The War Over Iraq. San Francisco, CA: Encounter Books.

Ketcham, R. (1986) The Anti-Federalist Papers. London and New York: Penguin.

Kramnick, I. (1987) The Federalist Papers. London and New York: Penguin.

Kuhn, T. S. (1996) The structure of scientific revolutions. Chicago: Chicago University Press.

Kupchan, C. (2018) 'The Clash of Exceptionalisms', Foreign Affairs 97:2, pp. 139-149.

Kupchan, C. (2013) No-One’s World. Oxford: Oxford University Press.

Lakatos, I. (1970) 'Falsification and the methodology of scientific research programmes'. In I. Lakatos, \& A. Musgrave (eds.), Criticism and the growth of knowledge, Cambridge: Cambridge University Press, pp. 91-196.

Layne, C. (2018) 'The US-Chinese power shift and the end of the Pax Americana', International Affairs 94:1, pp. 89-112.

Lundestad, G. (2012) The Rise and Decline of the American Empire. Oxford: Oxford University Press.

Maier, C. (2007) Among Empires. Cambridge, MA: Harvard University Press.

Malinowski, B. (2001). Sex and repression in savage society. London: Routledge.

Mearsheimer, J. (2018) The Great Delusion. New Haven, CN: Yale University Press.

Muthu, S. (2003) Enlightenment Against Empire. Princeton: Princeton University Press.

Nagel, T. (1986) The View from Nowhere. New York: Oxford University Press.

Norrlof, C. (2018) 'Hegemony and inequality', International Affairs 94:1, pp. 63-88.

Nye, J. S. (2002) The Paradox of American Power. Oxford: Oxford University Press.

Nye, J. S. (2004a) Soft power. New York: Public Affairs.

Nye, J. S. (2004b) 'Is America an Empire?'. Project Syndicate 26 January. https://www.project-syndicate.org/commentary/is-america-an-empire [Accessed 6 October 2017].

Nye, J.S. (2016) Is the American Century Over? London and New York: Polity.

Pan, C. and Turner, O. (2017) 'Neoconservatism as discourse'. European Journal of International Relations 23:1, 74-96.

Panitch, L. and Gindin, S. (2004) Global Capitalism and American Empire. London: Merlin.

Panitch, L. and Gindin, S. (2013) The Making of Global Capitalism. London: Verso.

Parker, N. (2010) 'Empire as a Geopolitical Figure'. Geopolitics 15, 109-132.

Pomeranz, K. (2005) 'Empire and "Civilizing” Missions, Past and Present'. Daedalus 134:2, 34-45.

Pomper, P. (2005) 'The History and Theory of Empires'. History and Theory 44, 1-27.

Popper, K. R. (1970) 'Normal science and its dangers'. In I. Lakatos, \& A. Musgrave (Eds.), Criticism and the growth of knowledge (pp. 51-58). Cambridge: Cambridge University Press.

Popper, K. (2002). Conjectures and refutations, London: Routledge.

Rachman, G. (2011) Zero-Sum Future. New York: Simon \& Schuster.

Rorty, R. (1980). Philosophy and the mirror of nature. Princeton: Princeton University Press.

Ryan, M. (ed) (2010a) Neoconservatism and the New American Century. Basingstoke: Palgrave Macmillan.

Ryan, M. (2010b) “"Exporting Democracy”?, 1989-2008'. Diplomacy and Statecraft, 21, 491515.

Skinner, B. F. (1972). Beyond freedom and dignity. London: Jonathan Cape.

Sullivan, J. (2018). 'The World After Trump'. Foreign Affairs 97:2, 10-19.

Todd, E. (2001) After the Empire. London: Constable and Robinson. 
Tucker, R. and Hendrikson, D. (1990) Empire of Liberty. Oxford: Oxford University Press.

Vaïsse, J. (2010) Neoconservatism. Cambridge: Belknap Press.

Vasquez, J. (1997) 'The Realist Paradigm and Degenerative versus Progressive Research Programs'. American Political Science Review, 91:4, 899-912.

Wilson, W. (1918) 'The Fourteen Points'. Speech to United States Congress 8 January. New Haven, CT: The Avalon Project. http://avalon.law.yale.edu/20th_century/wilson14.asp [Accessed 6 October 2017].

Wittgenstein, L. (2001) Tractatus Logico-Philosophicus. London: Routledge.

Wolfowitz, P. (2019) 'Discussing US-Iran tensions'. CNN International, July 22. https://www.aei.org/press/discussing-us-iran-tensions-wolfowitz-on-cnninternationals-first-move-with-julia-chatterly/ [Accessed 29 August 2019].

Wolfowitz, P. (2018a) 'Discussing the legitimacy of the recent air strikes in Syria'. BBC Radio 4, April 20. https://www.aei.org/press/discussing-the-legitimacy-of-the-recent-airstrikes-in-syria-wolfowitz-on-bbc-radios-the-real-story/ [Accessed 29 August 2019].

Wolfowitz, P. (2018b) 'The Trump-Kim Summit'. Fox News, June 12. https://www.aei.org/press/discussing-the-outcome-of-the-trump-kim-summitwolfowitz-on-fox-business-networks-cavuto-coast-to-coast/. [Accessed 29 August 2019].

Wolfowitz, P. (2017) 'Discussing President Trump's Middle East policy'. American Enterprise Institute, 24 April. https://www.aei.org/press/discussing-president-trumps-foreignpolicy-and-the-middle-east-wolfowitz-on-the-global-politico-podcast/ [Accessed 6 October 2017].

Wolfowitz, P. (2017) 'What comes after the Syria strikes'. American Enterprise Institute, 11 April. http://www.aei.org/publication/what-comes-after-the-syria-strikes/ [Accessed 7 September 2019]

Žižek, S. (2013) 'Why the free market fundamentalists believe 2013 will be the best year ever'. The Guardian, $17 \quad$ February. http://www.theguardian.com/commentisfree/2013/feb/17/free-marketfundamentalists-think-2013-best [Accessed 6 October 2017]. 